\title{
Influence of Psycho-Socio-Economic Factors, Parenting Style, and Sibling Rivalry, on Mental and Emotional Development of Preschool Children in Sidoarjo District
}

\author{
Rahma Fauziyah'), Harsono Salimo², Bhisma Murti1) \\ 1)Masters Program in Public Health, Universitas Sebelas Maret \\ 2)Department of Pediatrics, Dr. Moewardi Hospital, Surakarta
}

\begin{abstract}
Background: Preschool development is an influential basic stage for further development. Parents and siblings have an important role for a child's development. Parenting may be the best tool for the development of complete and integrated childhood personality. This study aimed to examine the influence of psycho-socio-economic factors, parenting style, and sibling rivalry, on mental and emotional development of preschool children.

Subjects and Method: This was an analytic observational study using cross sectional design. The study was conducted at 4 Community Health Centers, Sidoarjo District, East Java, from March to May 2017. A sample of 120 preschool children were selected for this study by multistage random sampling. The dependent variable was mental and emotional development. The independent variables were maternal education, family income, number of children, belief of child value, parenting style, and sibling rivalry. The data were collected by a set of questionnaire. Path analysis was employed for data analysis.

Results: Mental and emotional development was directly affected by authoritative parenting style $(\mathrm{b}=4.81 ; 95 \% \mathrm{CI}=3.05$ to $6.56 ; \mathrm{p}=<0.001)$ and sibling rivalry $(\mathrm{b}=2.45 ; 95 \% \mathrm{CI}=0.92$ to 3.99 ; $\mathrm{p}=0.002)$. Authoritative parenting style was positively affected by maternal education $\geq$ senior high school $(b=2.14 ; 95 \% \mathrm{CI}=0.03$ to $4.24 ; \mathrm{p}=0.046)$, family income $\geq$ minimum regional wage $(\mathrm{b}=1.41$; $95 \% \mathrm{CI}=0.07$ to $2.75 ; \mathrm{p}=0.038)$, and positive belief of child value $(\mathrm{b}=1.34 ; 95 \% \mathrm{CI}=0.01$ to 2.68 ; $\mathrm{p}=0.049)$. Family income was affected by maternal education $\geq$ senior high school $(\mathrm{b}=2.84 ; 95 \%$ $\mathrm{CI}=1.85$ to $3.83 ; \mathrm{p}<0.001)$. Sibling rivalry was affected by number of children $\geq 2(\mathrm{~b}=1.85 ; 95 \% \mathrm{CI}=$ 1.06 to $2.65 ; \mathrm{p}<0.001)$. Number of children $\geq 2$ was affected by positive belief of child value $(b=$ $3.77 ; 95 \% \mathrm{CI}=2.27$ to 5.27 ; $\mathrm{p}<0.001$ ).

Conclusion: Mental and emotional development is directly affected by parenting style and sibling rivalry. It is indirectly affected by maternal education, family income, belief of child value, and number of children.
\end{abstract}

Keywords: parenting style, sibling rivalry, mental development, emotional development, preschool children

\section{Correspondence:}

Rahma Fauziyah. Masters Program in Public Health, Universitas Sebelas Maret. Jl. Ir. Sutami 36 A Surakarta 57126, Central Java, Indonesia. Email: rahma2niez@yahoo.com. Mobile: +6281230701591

\section{BACKGROUND}

$\overline{\text { Education is important for human life. The }}$ educational process can occur anytime and anywhere. One place where the education process takes place is the family environment. Education cannot be separated from the role of the family (Yuliati, 2012). The first child's contact is with the family. Parents have an important role in the development and education of a child, which is responsible for educating, nurturing, and guiding their children to reach certain stages so that in the end a child is ready to live in society. 
Besides parents, the closest person seen by a child is a sibling. Relationships with siblings are the most basic relationship before we enter the world of society. This will be a solid foothold when the interactions between siblings go well, and will be a big collapse when the relationship between siblings is not good. This is because the influence of the siblings themselves is very strong. The number of siblings has its own influence on children's development. Children with a small number of siblings tend to fight more often than children who have many siblings (Putri, 2013). Maternal education greatly influences mothers in giving equal attention to children. Children who feel they do not receive attention, discipline, response, and treatment just like their siblings will become angry and jealous of their siblings, and this is what is called Sibling Rivalry.

Sibling rivalry can be shown by aggression and regression behaviors. In addition, when parents cannot minimize competition between siblings, more serious, and more complex impacts can occur. Parenting style applied by parents at home affects a child's tendency to compete with his siblings (Kurniani, 2012).

This past year, mental emotional disorders have become the main focus and attention in the medical community or in the general public. The study from Weitzman (2011) states that the incidence of emotional mental disorders in Germany is around $3-10 \%$, in the United States around $17-20 \%$, while in the State of New Zealand and New Zealand around 5-10\%. In Indonesia, the incidence rate is still uncertain, although this disorder is quite common. The study conducted in Sragen found that the prevalence of mental emotional disorders in children aged 3-5 years was $74.2 \%$. If this problem cannot be resolved it will have an impact on the maturation of children's character (Restiti, 2012).

Preschool age is a golden period of child development (Hurlock, 1995). A study conducted by Nurmalitasari (2015) explains that mental emotional development for preschool age is a basic development because the potential of the child's brain during this period will affect the child's psychological.

Mental development is related to mental health in children. Mental health is a condition that allows optimal physical, intellectual and emotional development. Mental emotional problems that are not solved will have a negative impact on children's development, especially on the maturation of their character, this results in the occurrence of mental emotional disorders that can be in the form of high-risk behavior. Handling and analyzing the emotional needs of preschoolers requires early detection of growth and development. Through early detection, it can be seen the deviation of child development early on, so that prevention efforts, stimulation, healing and recovery can be given with clear indications during critical periods of the growth process.

The purpose of this study was to analyze psychosocial economic factors, parenting style and sibling rivalry on the mental emotional development of preschool children.

\footnotetext{
SUBJECTS AND METHOD

\section{Study Design}

The study was an observational analytic using a cross sectional design approach. The time of study implementation was in March to May 2017 in 4 kindergarten schools in Sidoarjo District.
}

\section{Population and Sample}

The population in this study were all preschool children in Sidoarjo District. A 
sample of 120 children was selected by multistage random sampling.

\section{Study Variables}

The dependent variable was mental emotional development. The independent variables were education, income, number of children, children's value beliefs, parenting style, and the incidence of sibling rivalry.

\section{Operational Definition of Variables} The operational definition of the variable family income was income that was used as a source of the family's economy for 1 month. Education was the last formal education level that has been completed by a child's mother. The number of children was the number of children they have. Belief of children value was the functions performed or fulfilled of the parents' needs by children. Parenting style was an overall interaction between parents and children, where parents had the goal of stimulating certain things to their children by changing the behavior, knowledge, and values that were considered most appropriate by parents, so that children could be independent, grew and developed in a healthy and optimal. Sibling rivalry was a competition between siblings in one family, where in that condition there were children who were especially to get affection or love from parents. Mental emotional development was something that was related to the process of developing a child's mood that affected the adjustment to the surrounding environment.

\section{Study Instrument}

A questionnaire was used for collecting quantitative data. Quantitative data analysis used path analysis run on Stata 13 . Based on the results of the total item correlation test, it was found that the measurement of belief of child value, parenting style, and sibling rivalry incidence with $\mathrm{r}$ count $\geq 0.20$ and Cronbach's Alpha $\geq 0.70$, so that all questions were declared reliable. The results of the questionnaire reliability test can be seen in Table 1 .

Table 1. Reliability test results

\begin{tabular}{lcc}
\hline \multicolumn{1}{c}{ Variable } & Item Total Correlation (r) & Alpha Cronbach \\
\hline Belief of child value & $\geq 0.25$ & 0.74 \\
Parenting style & $\geq 0.35$ & 0.91 \\
Incidence of sibling rivalry & $\geq 0.32$ & 0.85 \\
\hline
\end{tabular}

\section{RESULTS}

\section{Sample characteristics}

Characteristic dimensions of 120 mothers and preschool children. Table 2 shows that out of 120 study subjects, $70.8 \%$ were educated $\geq$ Senior High School. As many as $63.3 \%$ families had high income. As many as 50\% mothers had $\geq 2$ children, $68.3 \%$ had positive belief of child value, $72.5 \%$ had authoritarian and permissive parenting style. Low sibling rivalry was $51.7 \%$.

\section{Bivariate analysis}

Table 3 showed the results of bivariate analysis. Table 3 showed that there were relationships between maternal education $(\mathrm{OR}=4.85$; $95 \% \mathrm{CI}=1.71$ to $13.70 ; \mathrm{p}=0.002$ ); family income $(\mathrm{OR}=3.84 ; 95 \% \mathrm{CI}=1.57$ to $9.34 ; \mathrm{p}=$ o.002); number of children $(\mathrm{OR}=2.25 ; 95 \%$ $\mathrm{CI}=1.04$ to $4.83 ; \mathrm{p}=0.036)$; belief of child value $(\mathrm{OR}=11.11 ; 95 \% \mathrm{CI}=3.16$ to 39.01$)$; $\mathrm{p}<0.001)$; parenting style $(\mathrm{OR}=56.92 ; 95 \%$ $\mathrm{CI}=15.12$ to 214.18$) ; \mathrm{p}<0.001)$; sibling rivalry incidence $(\mathrm{OR}=4.03 ; 95 \% \mathrm{CI}=1.81$ to 8.98$)$; $\mathrm{p}<0.001$ ) with mental emotional development.

Table 2. Sample Characteristics 
Journal of Maternal and Child Health (2017), 2(3): 233-244

https://doi.org/10.26911/thejmch.2017.02.03.05

\begin{tabular}{|c|c|c|}
\hline Characteristics & $\mathbf{n}$ & $\%$ \\
\hline \multicolumn{3}{|l|}{ Education } \\
\hline$<$ Senior High School & 35 & 29.2 \\
\hline$\geq$ Senior High School & 85 & 70.8 \\
\hline \multicolumn{3}{|l|}{ Income } \\
\hline < Regional Minimum Wage (Rp 3,290,800) & 44 & 36.7 \\
\hline$\geq$ Regional Minimum Wage (Rp 3,290,800) & 76 & 63.3 \\
\hline \multicolumn{3}{|l|}{ Number of Children } \\
\hline$<2$ & 60 & 50.0 \\
\hline$\geq 2$ & 60 & 50.0 \\
\hline \multicolumn{3}{|l|}{ Belief of child value } \\
\hline Negative & 38 & 31.7 \\
\hline Positive & 82 & 68.3 \\
\hline \multicolumn{3}{|l|}{ Parenting style } \\
\hline Authoritarian, permissive & 87 & 72.5 \\
\hline Authoritarian & 33 & 27.5 \\
\hline \multicolumn{3}{|l|}{ Incidence of sibling rivalry } \\
\hline Sibling rivalry incidence & 58 & 48.3 \\
\hline Sibling rivalry does not occur & 62 & 51.7 \\
\hline \multicolumn{3}{|l|}{ Mental emotional development } \\
\hline Poor & 77 & 64.2 \\
\hline Good & 43 & 35.8 \\
\hline
\end{tabular}

Table 3. Bivariate analysis of study variable

\begin{tabular}{lcccc}
\hline \multirow{2}{*}{ Independent Variable } & OR & \multicolumn{2}{c}{ CI (95\%) } & \multirow{2}{*}{ power } \\
\cline { 3 - 4 } & & $\begin{array}{c}\text { Upper } \\
\text { Limit }\end{array}$ & p \\
\hline Maternal education $\geq$ Senior High School & 4.85 & 1.71 & 13.70 & 0.002 \\
Family income $\geq$ Regional Minimum Wage & 3.84 & 1.57 & 9.34 & 0.002 \\
Number of children $\geq 2$ & 2.25 & 1.04 & 4.83 & 0.036 \\
Positive belief of child value & 11.11 & 3.16 & 39.01 & $<0.001$ \\
Authoritarian parenting style & 56.92 & 15.12 & 214.18 & $<0.001$ \\
Incidence of sibling rivalry & 4.03 & 1.81 & 8.98 & $<0.001$ \\
\hline
\end{tabular}

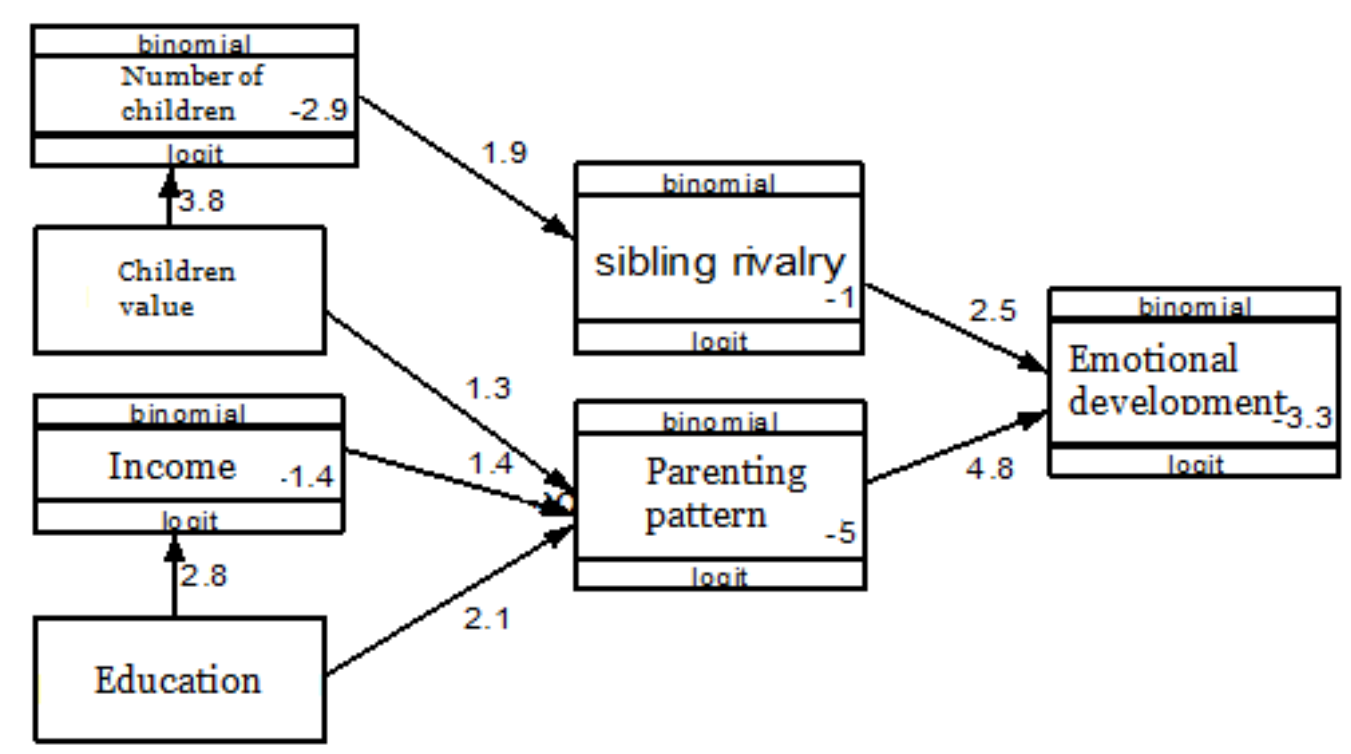

Figure 1. Structural model of path analysis 

Figure 1 shows the structural model with estimation. Indicators that show the suitability of the path analysis model are the number of measured variables identified along with the number of endogenous variables, exogenous variables, and parameters to be estimated. This stage calculates the degree of freedom (df) which indicates whether the path analysis can be done or not. Path analysis can be done if $\mathrm{df}$ $>0$, while the identification of path analysis models this time is obtained $\mathrm{df}$ is 14 and is called over identified which means path analysis can be done.

The results of path analysis can be seen through Table 5. The emotionalmental development of preschool children was influenced by the occurrence of sibling rivalry and parenting style.

Children from parents who had authoritative parenting had an average logodd of good mental emotional development 4.81 higher than children from parents with authoritarian and permissive parenting $(b=4.81 ; 95 \% \mathrm{CI}=3.05$ to 6.56 ; $\mathrm{p}<0.001)$.

Children who faced high sibling competition had logically developed 2.45 good mental emotional higher than children with low sibling competition $(b=2.45 ; 95 \% \mathrm{CI}=$ 0.92 to $3.99 ; p=0.002)$. Parental style were influenced by maternal education, family income, and belief of child value. Parents

Table 5. Path analysis result

\begin{tabular}{|c|c|c|c|c|c|}
\hline \multirow[b]{2}{*}{$\begin{array}{l}\text { Independent } \\
\text { Variable }\end{array}$} & \multirow[b]{2}{*}{ Dependent Variable } & \multirow{2}{*}{$\begin{array}{c}\text { Path } \\
\text { coefficient } \\
\text { (b) }\end{array}$} & \multicolumn{2}{|c|}{ CI (95\%) } & \multirow[b]{2}{*}{$\mathbf{p}$} \\
\hline & & & $\begin{array}{l}\text { Upper } \\
\text { Limit }\end{array}$ & $\begin{array}{l}\text { Lower } \\
\text { Limit }\end{array}$ & \\
\hline \multirow{3}{*}{$\begin{array}{l}\text { Direct effect } \\
\text { Mental and emotional } \\
\text { development }\end{array}$} & & & & & \\
\hline & $\leftarrow \quad \begin{array}{l}\text { Authoritarian parenting } \\
\text { style }\end{array}$ & 4.81 & 3.05 & 6.56 & $<0.001$ \\
\hline & $\leftarrow \quad$ Strong sibling rivalry & 2.45 & 0.92 & 3.99 & 0.002 \\
\hline Parenting style & $\leftarrow$ High education & 2.14 & 0.03 & 4.24 & 0.046 \\
\hline & $\leftarrow$ High income & 1.41 & 0.07 & 2.75 & 0.038 \\
\hline & $\leftarrow$ Positive children value & 1.34 & $<0.01$ & 2.68 & 0.049 \\
\hline Income & $\leftarrow$ High education & 2.84 & 1.85 & 3.83 & $<0.001$ \\
\hline
\end{tabular}

who had higher education had logodd of authoritative parenting 2.14 higher than parents with low education $(b=2.14 ; 95 \% \mathrm{CI}=$ 0.03 to $4.24 ; \mathrm{p}=0.046$ ).

Parents who had high opinions had log odds of authoritative parenting 1.41 higher than parents with low income $(\mathrm{b}=$ $1.41 ; 95 \% \mathrm{CI}=0.07$ to $2.75 ; \mathrm{p}=0.038$ ). Parents who had a belief in the value of a positive child had logodd of authoritative parenting 1.34 higher than parents with negative children's beliefs $(b=1.34 ; 95 \% \mathrm{CI}$ $<0.01$ to 2.68; $\mathrm{p}=0.049$ ).

Family income was influenced by education. Families with higher education level had a higher income with logodd was 2.84 higher than families with low education $(\mathrm{b}=$ 2.84; CI $95 \%=1.85$ to $3.83 ; \mathrm{p}<0.001)$. 
Journal of Maternal and Child Health (2017), 2(3): 233-244

https://doi.org/10.26911/thejmch.2017.02.03.05

\begin{tabular}{llllll} 
Sibling rivalry & $\leftarrow$ Number of children $\geq 2$ & 1.85 & 1.06 & 2.65 & $<0.001$ \\
Number of children & $\leftarrow$ Positive children value & 3.77 & 2.27 & 5.27 & $<0.001$ \\
\hline
\end{tabular}

Sibling rivalry events were influenced by the number of children. Children who had a number of siblings $\geq 2$ having a sibling rivalry with log odd 1.85 higher than children with 1 sibling $(b=1.85 ; 95 \% \mathrm{CI}=1.06$ to $2.65 ; \mathrm{p}<0.001$ ).

The number of children was influenced by belief of child value. Parents who ha$\mathrm{d}$ positive belief of child value had number of children log odd $\geq 2$ of 3.77 higher than parents with negative belief of child value ( $\mathrm{b}=3.77 ; 95 \% \mathrm{CI}=2.27$ to $5.27 ; \mathrm{p}<0.001$ ).

\begin{tabular}{l}
\hline DISCUSSION \\
\hline 1. Influence of Parenting Style on \\
Emotional Mental Development
\end{tabular}

The results of the analysis showed that there was a direct influence between parenting to the child's mental emotional development and was statistically significant. Parenting was the active role of parents in the development of their children, especially when they were still at the preschool stage, to improve children's moral intelligence early on (karma, courtesy, rules of religious and moral norms, ethics).

One important aspect in parent and child relationships was the parenting style applied by parents. Authoritative parenting style was responsive, appreciative and engaged children in making decisions. Parents who applied authoritative parenting tended to be more confident and were able to get along with their peers. Authoritarian parenting style required children to follow the instructions of their parents, gave strict limits and did not give children the opportunity to argue. Parents who applied this paenting style made children suspicious, children did not feel happy, and were awkward when dealing with peers. Permissive parenting style tended to let their child do whatever they want (Baumrind, 1991).

This was in line with a study conducted by Restiti (2012) that children's development was strongly influenced by social agents. The most important thing in the process of social development was the family, parents and siblings. Children as part of family members, in their growth and development would not be separated from the environment that cared for and nurtured them. Parenting style about growth and development, greatly helped children reach and pass growth and development according to their normal age level. Knowing better about children's growth and development was expected to grow and develop their children more optimally so that in the future they will produce a better generation of successors.

Another suitable study was conducted by Kustanti (2014) which stated that hard care predicted aggressive behavior or externalization. This would result in parent-child relationships. Parenting style would shape character and personality in the child's own development. Good parenting by always expressing affection (hugging, kissing, giving praise), practicing emotions and controlling children would result in children feeling cared for and would be more confident, so this would form a good child.

\section{Influence Sibling Rivalry Incidence on Emotional Mental Development}

The results of the analysis showed that there was a direct influence between the incidence of sibling rivalry on the mental emotional development of the child. These results were statistically significant.

Sibling rivalry in children had an influence on children, the influence or impact of sibling rivalry on children was divided 
into three parts, namely the impact on oneself, on siblings and on others. The impact of sibling rivalry on oneself was the existence of regression behavior, low self efficacy. The impact of sibling rivalry on siblings was that the child was aggressive, did not want to share with siblings, did not want to help and complained about the siblings. In addition to its impact on oneself and the impact on siblings, sibling rivalry also affects other people. When the pattern of relations between children and siblings is not good, it often happen that the bad relationship patterns will be brought by children to the pattern of social relations outside the home (Ayu, 2013).

Sibling rivalry incidence resulted in competition between siblings. With this problem, the child would try to overcome the conflict. Learning was a basic factor in social adjustment because through learning, response patterns would develop that would shape the child's personality. Learning in a social adjustment process was behavior modification since the initial phases and continued throughout life and was strengthened by personal maturity. If individuals had been able to overcome the conflict, individuals would make social adjustments in different situations more easily.

Facing sibling rivalry incidence, children are not always able to adjust themselves, because sometimes there are certain obstacles that cause unsuccessful adjustments (Hanum, 2015). Unsuccessful adjustments are usually referred to as mal-adjustments. Failure to make these adjustments will lead to tension, wrong behavior, nondirection, emotion, unrealistic, aggressive attitude, and so on. Children who can make social adjustments correctly will show no emotional tension, no fractionation, ability to learn, appreciate experience, be realistic and objective.

\section{Influence of Maternal Education on Emotional Mental Development}

Based on the results of path analysis in this study, it was shown that there was an indirect influence of maternal education on emotional mental development of children and it was statistically significant.

Educated people determined behaviors that appeared in attitudes, speech and relationships, so that this could also affect self-development for a child. High parental education made it easy to instill interest in learning with children. While parents with low education tended to entrust children's education to school. The application of education in the family had a very positive impact on the development of children both at home and outside the home. Therefore, parents should have a level of education and knowledge in line with the changing times. It is expected that better education owned by parents will be able to direct their children towards a better future.

This is in line with the study of Az-mita (2011) that mothers who were highly educated would be easy to absorb information about development in pre-school age children, so that knowledge about development in pre-school age children is better. But on the contrary, low-educated mothers would experience obstacles in the absorption of information about development in preschool age children so that knowledge about the development of pre-school age children was also lower. This mother's knowledge would obviously affect the mother in providing parenting style to the child. A well-informed mother would provide good care for children so that children's development will be good.

\section{Influence of Family Income on Emotional Mental Development of Preschool Children}

Based on the results of path analysis, this study indicated that there was an indirect 
influence of family income on the mental emotional development of children and it was statistically significant.

The family income per month is one of the factors that play a role in family life (Khalid et al, 2015). Considering that at present, all basic needs are becoming more expensive and increasing. Family income is certainly something very important to sustain the family economy. Economically, parents who have large incomes will certainly find it easier to fulfill all the necessities of life in their families, while for parents who have less income, it will certainly tend to be more difficult to meet the needs of their families and this will certainly affect family life.

The results of this study are in line with the study of Azmita (2011) explained that one's work would describe the activities and levels of economic well-being that would be obtained. Working mothers had a better level of knowledge than mothers who did not work, because working mothers would have more opportunities to interact with others, so they had more opportunities to get information about their situation. Working mothers would not have much free time so it was difficult to use their spare time. In addition, working mothers had fewer opportunity to increase knowledge about preschool age children development than those who did not work.

On the other hand, mothers who did not work would find it easier to obtain information to increase knowledge about pre-school age children development than working mothers. This was because their workload was less than the working mothers. Mothers who worked would be more difficult to get knowledge about preschool children developments because of fatigue. Fatigue after work blocked the desire to gain knowledge about child development. Fatigue and tired conditions also reduced concentration in providing care for their children.

\section{Influence of Nuber of Children on Emotional Mental Development of Preschool Children}

Based on the results of path analysis, this study indicated that there was an indirect influence of the number of children on the mental emotional development of children and it was statistically significant.

According to Hurlock (2013), number of siblings tends to produce relationships that have more disputes than the large number of siblings. This is because if one family only has two children and they are often together, more disputes occur. If in one family there are only 2 children, parents expect them to be able to play and do various things together. Generally if there is a dispute, parents are more defending their younger siblings and expecting the first child to budge and keep an eye on the younger sibling.

A study conducted by Howe and Rechia (2012) shows that a large number of children in the family, even though their economic conditions are sufficient, will result in reduced attention and affection from their parents, especially if the distance of the child is too close. This can result in child development both physically and mentally.

The implications of small families for social and economic life are quite large. Social support such as caring for children from family members is increasingly directed with a small number of children, and has better educational opportunities than a large number of families. The more the number of children in the family, then there is a tendency for parents not to apply the parenting style maximally to children because their attention and time are divided between one child and the other child. Meanwhile, families with small 
numbers of children provide opportunities for children to learn to share and get attention from parents.

\section{Influence of Belief of Child Value on Emotional Mental Development of Preschool Children}

Based on the results of the path analysis, this study indicated that there was an indirect influence of the belief of child value that parents have on the mental emotional development of children and it was statistically significant.

It is likened to being entrusted by God to parents, a child has a certain value and demands the fulfillment of some consequences for his/her presence. Social backgrounds with different levels of education, health, customs or culture of a social group as well as different income or livelihoods, lead to different views about children.

Children have universal values, but the value of these children is strongly influenced by socio-cultural factors and others. What is meant by perceptions of the value of children by parents is a response in understanding the existence of children, which is an opinion to have among choices that are oriented to a thing that is basically open in situations that come from outside. Parents' views about the value of children can influence parents in providing care for children.

Parenting style of parents can be influenced by parents' beliefs of their children value, parents' hopes for children, parental education, parental assertive behavior, family climate and religious commitment. Latifah (2011) in his study interpreted parents' beliefs about children's development as parents' trust in changes in abilities acquired by children from the learning process. Where in the learning, the child uses his imagination, depicts something according to his mindset, compares things, compiles information in the child's memory, and does evaluation.

Parents who have positive belief of child value in seeing their children's development will emphasize more on the process of interaction between newly acquired knowledge and processing information in the individual. The implementation of parents' beliefs in their children's development is the number of opportunities that parents give for their children to explore their environment. Parents need to take an active role in interpreting a new experience that children get in the process of exploring the surrounding environment.

Parents who have belief in seeing children's development, prioritize the process of development from within the individual. Believing parents, placing children as subjects of organizing new knowledge and as small inventors from the results of exploration carried out on the environment around them. Parents who has positive belief of children values give more freedom to children to explore their environment. Parents act as controllers and facilitators. As a controller, parents are not directly involved with children's activities. This is one of the characteristics of parental involvement in authoritative parenting. Eka (2014) said that parents who apply authoritative parenting have an involvement where parents enter the lives of children but do not provide help directly.

Child development is strongly influenced by social agents. The most important thing in the process of social development is the family, parents and siblings. Brother competition is primarily a sensitive problem because the child does not only compare himself with his other siblings but he also assesses how his parents compare with other siblings. Parenting style will shape character and personality in the child's own development. Good parenting 
style by always expressing affection (hugging, kissing, giving praise), practicing emotions and controlling children will result in children feeling cared for and will be more confident, so this will shape the good personality of a child.

\section{REFERENCE}

Anonim (2012). Peran Keluarga Mengendalikan Kenakalan Anak. http://www. sekolahdasar.net/2012/o9/peran-keluarga-dalam mengendalikan-kenakalan-anak.html. Diakses tanggal 10 Desember 2016.

Ayu SR (2013). Dampak Sibling Rivalry (Persaingan Saudara Kandung) Pada Anak Usia Dini. Journal. unnes. ac.id.

Azmita N (2011). Faktor Dominan Karakteristik Ibu yang Berhubungan dengan Pertumbuhan dan Perkembangan Balita Usia 2-5 tahun di Wilayah Kerja Puskesmas Nanggalo Kota Padang. Fakultas Keperawatan, Universitas Andalas.

Baumrind D (1991). The Influence of Parenting Style on Adolescent Competence and Substance Use. Journal of Early Adolescent 11(1): 56-95.

Baumrind D (2004). Pola Asuh Otoritas Orang Tua. Jakarta: Yayasan Obor Indonesia

Briggs R (2012). The Importance of Social Emotional Development in Early Childhood. Pediatrics For Parent.

Damayanti M (2011). Masalah Mental dan Emosional pada Remaja, Deteksi dan Intervensi. Sari Pediatri 13 (1): 45-51.

Desy W (2013). Hubungan Antara Pola Asuh Orang Tua, Motivasi Belajar, Kedewasaan Dan Kedisiplinan Siswa Dengan Prestasi Belajar Sosiologi Siswa di Wonogiri. Skripsi.Fakultas Keguruan Dan Ilmu Pendidikan Universitas Sebelas Maret Surakarta.
Eka N (2014). Pola Asuh Orang Tua Dalam Membentuk Kecerdasan Emosional Anak. Yogyakarta.

Hanum AL, Aziz A, Hidayat A (2015). Faktor Dominan Pada Kejadian Sibling Rivalry Pada Anak Usia Prasekolah. Program Studi S1 Keperawatan Fakultas Ilmu Kesehatan 1 Universitas Muhammadiyah Surabaya. THE SUN 2(2).

Hariyanti M (2016). Sibling Rivalry Pada Anak yang Kesundulan. Skripsi. UIN Maulana Malik Ibrahim : Malang

Hakvoort, Esther M, Bos HMW, Balen F, Hermanns JMA (2010). Family Relationships and the Psychosocial Adjustment of School-Aged Children in Intact Families. The Journal of Genetic Psychology 171 (2): 182-201.

Howe \& Rechia (2012). Sibling Relations and Their Impact on Children's Development. Centre for Research in Human Development, Concordia University, Canada. http://www.childencyclopedia.com/documents/HowerecchiaANGxp.pdf. Diakses 29 November 2016.

Hurlock EB (1995). Psikologi Perkembangan. Penerjemah: Istiwidiyanti dan Soedjarwo. Jakarta: Erlangga.

Hurlock EB (2013). Psikologi Perkembangan: Suatu Pendekatan Sepanjang Rentang Kehidupan, Edisi 5. Alih bahasa: Istiwidayanti dan Soedjarwo. Jakarta: Erlangga

Ika F, Luthfatul L, Dewi N (2010). Hubungan Tipe Pola Asuh Orang Tua Dengan Emotional Quotient (EQ) Pada Anak Usia Prasekolah (3-5 Tahun) di Tk Islam Al-Fattah Sumampir Purwokerto Utara. Jurnal keperawatan Soedir$\operatorname{man} 5(1)$.

Isfandari S (2012). Gejala Gangguan Mental Emosional pada Anak. Buletin Penelitian Kesehatan 25 (3): 53-60. 
Ita L (2011). Penyebab Terjadinya Sibling Rivalry Pada Anak Usia Sekolah di Kelurahan Jomblang Kota Semarang. http://digilib.unimus.ac.id. Diakses pada tanggal 29 November 2016.

Junaidi W (2010). Macam-macam Pola Asuh Orang Tua. http:www.blogspot. com. Diunduh pada 22 November 2016.

Kementrian Kesehatan (2012). Pedoman Pelaksanaan Stimulasi, Deteksi, Intervensi Dini Tumbuh Kembang Anak Ditingkat Pelayanan Kesehatan Dasar. Jakarta.

Khalid H, Khawar K, Fawad M, Farhat M, Imran M, Shanawaz M, Shahid M, Yousaf P, Saleem Q, Ahmed S, Sarwar R, Ali KH, Humayun A (2015). Age of Menarche in Realtion to Sosioeconomic Status BMI, Phisycal Activity and Stress among High School Girl. Proceeding S.Z.P.G.MI 29: 35-40.

Kurniani D (2012). Hubungan Pola Asuh Orang Tua Dengan Kejadian Sibling Rivalry Pada Anak Usia 3-5 Tahun Di Puskesmas Tirto I. Sekolah Tinggi Ilmu Kesehatan Muhammadiyah. Pekalongan.

Kustanti (2014). Pengaruh Pola Asuh Otoriter Orang Tua terhadap Konsep Diri Anak. Jurnal Motivasi 2 (1) http:/ jos.unsoed.ac.id/index.php/keperawa tan/article/view/206. Diakses 10 September 2016

Latifah, Melly, Mulyani, dan Sri Rahayu (2011). Studi Nilai Anak, Jumlah Anak Yang Diinginkan, Dan Keikutsertaan Orang Tua Dalam Program KB. Fakultas Ekologi Manusia, Institut Pertanian Bogor. Jur. Ilm. Kel. \& Kons., Januari 4(1): 37-45.

Murti B (2013). Desain dan Ukuran Sampel untuk Penelitian Kuantitatif dan Kua- litatif di Bidang Kesehatan. Yogyakarta: Gajah Mada University Press.

Nisa, Zuhrotun, Maghfuroh, Lilis, dan Supanik (2011). Hubungan Sikap Orang Tua Dengan Kejadian Sibling Rivalry Pada Anak Usia Toddler di Desa Gendong Kulon Babat Lamongan. SURYA 03(VII).

Nurmalitasari F (2015). Perkembangan Sosial Emosi pada Anak Usia Prasekolah. Program Magister Psikologi Fakultas Psikologi Universitas Gadjah Mada; Buletin Psikologi (23) 2.

Papalia E (2014). Menyelami Perkembangan Manusia (Experience Human Development). Jakarta: Salemba Humanika

Putri A (2013). Dampak sibling rivalry (persaingan saudara kandung) pada anak usia dini. Skripsi. Universitas Negeri Semarang

Restiti M (2012). Peranan Orang Tua Terhadap Perkembangan Sosial Emosional Anak Kelompok B Di Tk Pertiwi 1 Sragen Tahun Ajaran 2011/ 2012. Naskah Publikasi. Universitas Muhammadiyah.

Thompson J (2012). Implicit Belief about Relationship Impact the Sibling Jealousy Experience. http://www.lib. nscu.edu. Diakses 1 Desember 2016

Weitzman M, Roshenthal DG, and Liu YH (2011). Paternal Depressive Symptoms and Child Behavioral or Emotional Problems in The United States. Pediatrics 128(6): 1126-34.

Yuliati (2012). Hubungan Tingkat Pengetahuan Ibu dengan Reaksi Sibling Rivalry pada Anak Usia Prasekolah di TK Mranggen I Srumbung Magelang. Skripsi. Semarang. FIK Universitas Muhammadiyah Semarang. 